International Journal of English Literature and Social Sciences
Vol-6, Issue-2; Mar-Apr, 2021
Journal Home Page Available: https://ijels.com/
Journal DOI: $10.22161 /$ ijels

\title{
Politics of choice- deconstructing the idea of marriage
}

\author{
In light of 'Marriages are made,' 'Exercise book,' and 'Kallu'
}

\section{Arpita Chowdhury}

Department of English, Lady Sriram College for Women, University of Delhi, India

Received: 09 Jan 2021; Received in revised form: 03 Mar 2021; Accepted: 30 Mar 2021; Available online: 26 Apr 2021

(C)2021 The Author(s). Published by Infogain Publication. This is an open access article under the CC BY license

(https://creativecommons.org/licenses/by/4.0/).

\begin{abstract}
In this paper, I have attempted to talk about the idea of marriage largely based on three different texts that are 'Marriages are Made by Eunice D'souza, 'Exercise Book' by Rabindranath Tagore and 'Kallu' by Ismat Chugtai. The constant subjugation of the female voice is examined through various shreds of evidence. It is quite apparent that women have hardly a say in choosing their life partner and it's the overarching dominance of the family to which the girls have to succumb. In 'Marriages are made' by Eunice D'souza we see the complete dehumanization of a woman who is reduced to a mere product. Tagore in 'Exercise Book' attempts to enquire the prospects of child marriage whereas in Ismat Chugtai's 'Kallu' we see the muted gender. Hence, we will see the ways in which authors bring to fore the idea of power struggles in the gendered narrative.
\end{abstract}

Keywords-Chugtai, D'souza, Gender, Marriage, Tagore, struggle.

\section{INTRODUCTION}

The attempt to actively deconstruct the stereotypical notions and orthodox customs of marriage help us reflect on the various turmoils a woman or a girl has to go through. Whether it's denying her right to read or testing her complexion and tooth cavity, she has to face every humiliation. Still, she is the one who has to succumb to the 'expected' behaviour. Another significant issue lies in the aspect of the woman's choice or say in her own marriage. The extent to which a woman is allowed to practice agency in taking her life decisions is also debatable. In 'Marriages are made' by Eunice D'souza we see the complete dehumanization of a woman who is reduced to a mere product. Tagore in 'Exercise Book' attempts to enquire the prospects of child marriage whereas in Ismat Chugtai's 'Kallu' we see the muted gender. On the basis of all the texts, I will try to deal with the issues of marriage and the limited role of women in it.

\section{DELVING DEEPER INTO THE TEXTS}

My cousin Elena is to be married

The formalities have been completed:
Her family history examined

for T.B and madness

her father declared solvent

her eyes examined for squints

her teeth for cavities...(Marriages are made, 1-8)

'Marriages are made' by Eunice D'souza attempts to mock the orthodox marriage traditions where women are treated as products openly available in the market. The idea of 'making' marriage highlights the notions of marriage being a trade thus, portraying the objectification of women. D'souza actively deconstructs the romantic proposition associated with marriage.

Next year, when the little girl was nine years old, the strains of the shehnai could be heard one morning in the house. It was Uma's wedding day. (Exercise book)

Rabindranath Tagore moves inside a traditional Bengali household where education is only available to the boys and girls are meant to get married, look after the domestic chores and bear children. The sheer irony of the name 'Uma' which means 'Goddess Durga' who is an embodiment of women power seems to be a deliberate attempt by Tagore to question the patriarchal norms. 
Salima became tearful. Everyone had been teasing her...Mumani's cantankerous chastisement fell upon our ears like the sound of wedding trumpets. (Kallu)

The appropriation of caste distinctions is reflected by Chugtai in her short story. While the journey of Kallu is the main thought line of the text, however, the underlying notions of marriage is constantly present in the story. While Salima was a toddler she agreed to Kallu's marriage proposal but the fact that her agreement is rejected and accepted based on the wealth of Kallu is an extreme mockery of the so-called 'rigid' traditions.

\section{POET/ AUTHOR'S TAKE ON THE NARRATIVE}

The writers perspective needs to be analysed first before go into deconstructing the notions of marriage in each and the way it is depicted.

\subsection{Marriages are made}

"D'souza means to move out of this dismal space and to subvert the 'discourse of silence'." (Krishnaswamy, 2008 , \#) De Souza's critique of the discrimination based on gender is contextualized in relation to other identity markers. She makes a sarcastic comment on the orthodox Catholic marriage culture where the woman needs to be checked before 'buying'

\subsection{Exercise book}

Exercise-Book Khata explores another forceful interruption of social norms, thereby, curbing the spirit of Uma. Tagore's critical response to the ruthless irony at his depiction of how the female self is curtailed by forceful interventions of patriarchy. Uma is married when she is a child against her will. The regressive traditions of society rob a child of her right to be educated.

\subsection{Kallu}

Chugtai realistically exposed the conditions, exploitations and struggle of women in the shackles of patriarchy. Though the story is largely based around class division and the journey of Kallu. Through "Kallu" Ismat Chughtai had powerfully dealt with the issue of child labour. Another layer that story beholds is that of the gender roles. Though we see Kallu rising high on the social ladder, however, we never see him talking to Salima bi to ensure whether she wants to marry him or not. The silence of Salima Bi is significant to touch upon.
“It's like subjective isn't it, because someone's version of something being arranged might be another person's version of being forced..." (Sareena, 2016).

This very statement helps us infer the lack of consent in marriage especially from the girl/woman who is supposed to live with a person for her entire life. Through various shreds of evidence, we shall see how women are entrapped in the stereotypical notions of match-making. All the three authors in various spaces bring to fore this issue and enable the audience to ponder upon them.

Conventional Marriage as a cultural framework endows the regressive patriarchal system.

All three texts revolve around the idea of marriage, however, none of them gives a direct voice in the girl's mouth.

\subsection{Objectification}

In 'Marriages Are Made' the protagonist Elena is to be married. However the marriage is not a happy occasion for her, but rather, it is the time for her to be subjected to numerous humiliations to prove herself worthy of being married. In Christian theology, Eve was believed to have been created from Adam's rib. As Adam, the first man on the earth, remarks about Eve: "This is now bone of my bones, and flesh of my flesh, she shall be called woman because she was taken out of man" (Krishnaswamy, 2008, \#)

\subsection{Cultural construct}

Tagore while attempting to uphold the need for women's educational rights, traverses into the Comparison of Goddess Durga with Uma, the protagonist who will have to go back to her husband's house after four days. Uma is to be married off. Thus re-establishing the norm of women's identification based on their husband.

\subsection{Gender/Caste}

Salima $\mathrm{Bi}$ is never at the centre stage, the whole narrative considers her one innocent 'yes' while she was a little child as the confirmation. The story revolves around the caste-based struggles however the gendered narrative isn't out of sight. "By underscoring women's struggles against the oppressive institutions of her time she brings to her fiction an understanding of the female psyche that is unique, no other Urdu fiction writer has approached women's issues with the same degree of sensitivity and concern." (Naqvi, 2019, \#)

\section{CRITICAL ANALYSIS}

\section{SILENCE AND THE QUEST FOR CHOICE}


We see the overpowering presence of silence of the women in the three texts, whether it's Salima bi or Elena, they never speak in the first person, hence, muffling their real perspectives around their own marriage. Deconstructing the voices of the psyche, both Chugtai and D'souza confront the horrors of the societal frameworks sanctioned by socio-cultural approvals.

Tagore's Uma though takes active participation in expressing herself however, she is hardly able to rebel against her marriage. The underlying notions of child marriage and attitude towards Girls as 'paraya dhan' are extremely significant. With this girl, her exercise book, too, receives an intense humiliation in the sarcasm of her in-laws and nonchalance of her husband, Pyarimohan. Pyarimohan voices the prevalent social norm despising female education. (Roy, 2010, \#)

Navigating the extent of freedom available to the three women in terms of making a choice, the overarching presence of the dominating ideologies suppress the inherent right of the women.

\section{Why is Elena being examined like a product??}

Why the little girl Uma is married off even before she comprehends the idea of marriage?

Why is Salima never asked whether she wants to marry Kallu?

Based on a research study "An exploration into women's choice and premarital experiences of arranged marriages within a South Asian community in Britain (2016) " it has been found that "women experienced subtle pressure from their parents and the community, to ensure they uphold cultural duties. The premarital distress often led some women to subjugate their needs, and to accept and conform to alleviate psychological and emotional distress." The reason behind including this research conclusion is to substantiate the argument that in most cases it the women who have to face socio-cultural subjugation. In all three texts, we see women go through humiliation and social scorn. The presumption that the woman is ready for a certain marriage proposal questions the whole idea of choice and the freedom to choose one's partner.

The need for manifesting individual choice is genderspecific and largely not available for women in the stories.

$\rightarrow$ Francisco X. Noronha Prabhu can reject Elena if she is deemed unfit.

$\rightarrow$ Pyarimohan can stop Uma from studying

$\rightarrow$ Kallu can ask for Salima because he loves her.
The texts enquire into the commercial aspect of marriage literally and figuratively. A woman is considered to be an object who is presented in the marriage market. The whole idea of arranging and making negates the psychological and emotional aspects of two individuals coming together. The way Kallu's economical background affects the decision of Mumani highlights the ever-present materialist agendas of the families and also reflect on the prejudice of people against the economically weaker section. The stronger the cultural identity, the more likely they will encourage early marriage to meet the needs of the community rather than the individual's discretion (Mehrotra, 2016, \#). A strong sense of feeling dehumanised and objectified, as families would focus on facts on paper or physical attributes, and disregard the individuals' needs, emotions or personality.

\section{CONCLUSION}

In effect, the three different textual pieces written in different geographical spaces paint a similar picture of the conventional marriage systems. D'souza, Tagore, and Chugtai very vividly portray the hardships of women who have to fall prey to the societal construction of the marriage market. The critical commentary on this regressive structure is explicit, Thus, questioning the deliberate suppression of women's voices.

\section{REFERENCES}

[1] Krishnaswamy, N. (2008). Pt. 1: Roots and Blossoms. In Indian Poetry in English (Vol. I). Sarup \& Son. https://books.google.co.in/

[2] Mehrotra, G. R. (2016). South Asian Women and Marriage: Experiences of a Cultural Script. Springer Science+Business Media New York, 33:350-371(2016), 350-369. https://www.researchgate.net/

[3] Naqvi, T. (2019). "Voices of "Muted Gender" in the Short Stories of Ismat Chughtai." Aesthetique Journal for International Literary Enterprises (AJILE), JULY(2019), 91-97. https://www.researchgate.net/

[4] Patel, D. (2016). An exploration into women's choice and premarital experiences of arranged marriages within a South Asian community in Britain. An Interpretative Phenomenological Analysis. University of East London. Retrieved March, 2021, from https://repository.uel.ac.uk

[5] Roy, M. (2010). Scripting Women in Three Short Stories of Tagore. Rupkatha Journal on Interdisciplinary Studies in Humanities, 2(4), 596-603. http://rupkatha.com/V2/n4/20WomeninTagoreShortstories. pdf. Accessed 14022021

VI. WOMEN AND MARRIAGE TRADE 